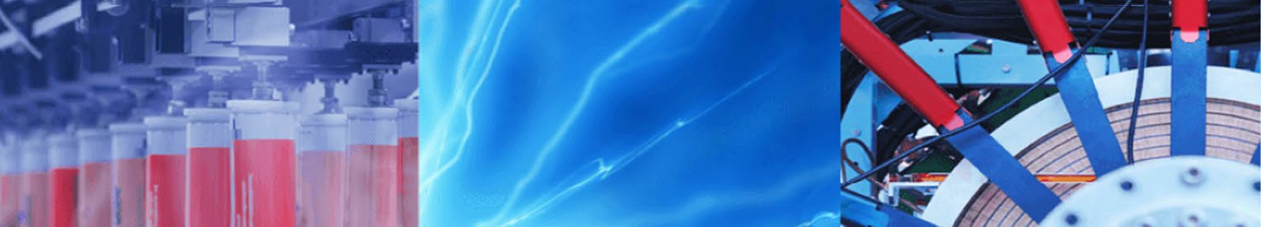

Research Article

\title{
The distribution of soil microbial parameters based on aggregate fractions in successional grassland restoration ecosystems on the Loess Plateau
}

\author{
Zhijing Xue ${ }^{1,2} \cdot$ Zhongming Wen $^{1} \cdot$ Zhengchao Zhou $^{2} \cdot$ Shaoshan An ${ }^{1}$
}

Received: 12 December 2019 / Accepted: 19 June 2020 / Published online: 3 August 2020

(c) Springer Nature Switzerland AG 2020

\begin{abstract}
Soil microbial biomass and microbial metabolic quotients have been identified as the most effective indicators of a response to ecosystem development and disturbance. In order to determine the effects of grassland restoration programs, we analyzed the distribution of soil microbial parameters in different aggregate fractions at $1 \mathrm{yr}$. (1 year), $10 \mathrm{yr}$. (10 years) and $30 \mathrm{yr}$ (30 years). Results show that $C_{\text {mic }}$ (soil microbial biomass carbon) and $P_{\text {mic }}$ (soil microbial biomass phosphorus) increased with grassland succession, the greatest values were concentrated at a micro-aggregate size. However, $q \mathrm{CO}_{2}($ soil microbial metabolic quotient) decreased as the years under restoration increased. $q \mathrm{CO}_{2}$ was significantly correlated with SOC (soil organic carbon), TN (soil total nitrogen), $P_{\text {mic }}$ (negatively) and $C_{\text {mic }}$ (positively). Natural succession of grassland alters soil microbial properties positively, which plays a major role in aggregate formation. The time under vegetation rehabilitation impacts soil microbial parameters at different aggregate sizes, macro-aggregate size is the key factor in soil stability improvement in the process of natural restoration, especially for the aggregate size of 2-3 mm.
\end{abstract}

Keywords Vegetation restoration · Recovered chronosequence · Soil microbial parameters · Soil microbial metabolic . Soil aggregate size

\section{Introduction}

Soil microbes are known to play a key role in terrestrial ecosystem functions, such as carbon and nutrient cycling, plant growth stimulation, and degradation of organic matter [24]. Vegetation restoration is regarded as an effective strategy for controlling intensive soil erosion and its extensive effects [7]. Grassland is the mot common terrestrial ecosystem on Earth with a crucial function of regulating climate and maintaining a balanced ecosystem [5]. The Loess Plateau of China covers $62.38 \times 10^{6}$ ha which includes $20.15 \times 10^{6}$ ha of grassland, with $91.2 \%$ of that area being occupied by natural grassland. But widespread stress practice, intensive cultivation, overgrazing and large-scale monocultures have caused the area to acquiesce to soil erosion and a series of related eco-environment problems [11]. The Grain to Green program, a national ecological restoration program implemented in 1999 , has made remarkable advances in vegetation recovery on the Loess Plateau [10]. Several countermeasures have been implemented including eco-environment rehabilitation using engineering and biological approaches [48]. Natural grassland protection and restoration is one of the important parts of a vegetation restoration program [23].

A growing body of ecological research on plant-microbe interactions in soil during vegetation restoration has recently been conducted. Positive and negative

$\triangle$ Zhengchao Zhou, zczhou@snnu.edu.cn | ${ }^{1}$ State Key Laboratory of Soil Erosion and Dry Land Farming on the Loess Plateau, Institute of Soil and Water Conservation, Northwest A\&F University, Yangling 712100, China. ${ }^{2}$ School of Geography and Tourism, Shaanxi Normal University, No. 620, West Chang'an Avenue, Chang'an District, Xi'an 710119, China. 
feedbacks between plants and soil microbes play central roles in early and later successional communities [38]. Soil structure, especially the spatial distribution of OM within the organic-mineral matrix of soil, exhibits control over microbial mediated decomposition processes in terrestrial ecosystems [29, 34]. Soil aggregates are structural units, where a group of primary soil particles cohere to each other more strongly than to other surrounding particles [4]. Research indicates that soil aggregates greatly impact the soil microbial biomass and mineral nutrients reserves $[15,46,53]$. Thus, the soil microbial biomass demonstrates a similarly positive relationship with soil structure, and microbial biomass shows significantly positive relationships with aggregate size and stability $[12,13,36,37]$. When assessing the effects of disturbances on soil quality, Anderson and Domsch [3] proposed the ratio of soil basal respiration to microbial biomass (microbial metabolic quotient, specific respiration of the biomass or $q \mathrm{CO}_{2}$ ), conceptually based on Odum's theory of ecosystem succession, is increasingly being used as an index of ecosystem development [30,50]. Soil microbial biomass basal respiration and microbial metabolic quotient all respond readily to disturbance effects and provide an effective early waning for the deterioration of soil quality $[8,35,49,50,57]$. They have been used as indicators of change in soil organic matter that occur in response to land use alteration, tillage practices and soil pollution [9, 32].

We hypothesize that the years under grassland restoration effects soil structure formation which consequently effects the distribution of soil microbial biomass and microbial metabolic quotient. The objectives of this study are to explain (1) soil microbiological parameters in which grassland restoration year displayed more sensitive, in the middle of the succession or later period. and (2) which scope of soil aggregate sizes can reflect soil aggregate stability, What is the different between $1 \mathrm{yr}$ and $30 \mathrm{yrs}$.

\section{Materials and methods}

\subsection{Study site description}

The study area was located in Chinese Loess Plateau, the south of Ningxia Province $\left(106^{\circ} 25^{\prime}-106^{\circ} 30^{\prime} \mathrm{E}\right.$, $\left.35^{\circ} 59^{\prime}-36^{\circ} 20^{\prime} \mathrm{N}\right)$. The region has a sub-arid climate characterized by seasonal rainfall with periodic local flooding and drought; the average annual temperature was $6^{\circ}$, and the average annual rainfall was $400-450 \mathrm{~mm}$. The rainy season lasted from July to September and the rainfall in July accounting for $24 \%$ of the annual rainfall. Most of the land is at altitude of $1800-2040 \mathrm{~m}$ and is closely dissected by steep galleys [1]. Grassland soils from three restoration years (30 years, natural grassland; 10 years, natural grassland; 1 year, abandoned grassland), were processed at the Yunwu Observatory for Vegetation Protection and Eco-environment.

\subsection{Soil sampling collection}

Undisturbed soil samples were collected from different restoration years in May 2016. For each restoration year, three sites in different locations were collected as replicates. An area of $50 \mathrm{~m} \times 50 \mathrm{~m}$ was selected for each site and within this area three $10 \mathrm{~m} \times 10 \mathrm{~m}$ plots were chosen for sampling. Soil profile was sampled by soil depth $0-20 \mathrm{~cm}$. There were 5 replications for each site were randomly taken by $200 \mathrm{~cm}^{3}$ plastic boxes and composited to obtain a fresh sample. Samples were taken from each plot and mixed to a bulk sample of about $1 \mathrm{~kg}$. After removing stones, roots and sieving at $<0.25 \mathrm{~mm}, 0.25-1 \mathrm{~mm}$, 1-2 mm, 2-3 mm, 3-5 mm, $>5 \mathrm{~mm}$, the sieved fresh soil samples were stored in ice boxes, and immediately transferred to the laboratory. Hence, we obtained 54 soil samples in total.

Care was taken during sample preparation to minimize moisture loss and samples were divided in two. One section was preserve in $4^{\circ} \mathrm{C}$ for soil microbial measurements. The other was air dried for basic soil characteristics analysis. The water-holding capacity was determined by saturating each $100 \mathrm{~cm}^{3}$ turf sample with water and allowing it to drain at field capacity under cover for $48 \mathrm{~h}$ at ambient temperature; Duplicate soil cores were dried at $105^{\circ} \mathrm{C}$ overnight to determine moisture content [1].

\subsection{Sampling analysis}

The soil samples were air dried and passed through a $2 \mathrm{~mm}$ sieve. The basic soil characteristics were analyzed through soil chemical and physical analyses [19]. Soil organic carbon was measured by wet digestion in a mixture of $5 \mathrm{ml}$ of $0.136 \mathrm{~mol} \mathrm{~L}^{-1}$ potassium dichromate and $5 \mathrm{ml}$ of concentrated sulfuric acid. Soil total nitrogen was measured using Kjeldahl digestion. Alkali-ExTR-N was measured using a micro-diffusion method in which $\mathrm{NH}_{3}$ was released from the soil sample by $\mathrm{NaOH}$ and then absorbed by boric acid. The ammonium borate product was titrated with $0.01 \mathrm{M}$ $\mathrm{HCl}$. Available phosphorus (Av-P) was extracted and measured in a buffered alkaline solution containing $0.5 \mathrm{M}$ sodium bicarbonate. The extracts were quantified calorimetrically at $660 \mathrm{~nm}$ with a spectrophotometer (UV2300, Hitachi, Tokyo, Japan) [54]. The readily available potassium was extracted from the soil with $1 \mathrm{~mol} \mathrm{~L}^{-1} \mathrm{NH}_{4} \mathrm{OAc}$ and was measured using flame photometry. The soil $\mathrm{pH}$ was measured in water $(1 / 2.5 \mathrm{w} / \mathrm{v})$, and the moisture content was assessed by drying the samples in an oven at $105^{\circ}$ overnight. 
Soil basal respiration was estimated through $\mathrm{CO}_{2}$ evolution at $25^{\circ} \mathrm{C}$ in samples incubated for 10 days [21]. Measurements were made in the laboratory at $50 \%$ of field water holding capacity (WHC). $\mathrm{CO}_{2}$ respired was trapped in $\mathrm{NaOH}$, and the residual $\mathrm{NaOH}$ was titrated with $\mathrm{HCl}$ [1].

The soil microbial biomass $\mathrm{C}, \mathrm{N}$ and $\mathrm{P}$ levels were determined using the fumigation-extraction method. A $15 \mathrm{~g}$ sample of oven-dried, field-moist-equivalent soil $(<2 \mathrm{~mm})$ was fumigated with chloroform for $24 \mathrm{~h}$ with the chloroform being removed by repeated evacuation. The soil was reinoculated with a small amount of unfumigated soil and incubated at a constant temperature (usually 22 or 25) for 10 days at field capacity or at $50 \%$ of its water-holding capacity (approximately - $0.01 \mathrm{MPa}$ ). An additional, unfumigated soil sample was used as a control $[20,21]$. The soil microbial biomass carbon level was determined immediately using a TOC analyzer or the sample was preserved at -18 (Phoenix 8000, Tekmar-Dohrmann, Mason, $\mathrm{OH}$, U.S.A.). A $k_{C}$ value of 0.4 was chosen to calculate the total soil microbial biomass $C$ [51]. To determine soil microbial biomass $\mathrm{N}$, fumigated and unfumigated samples were extracted via potassium persulfate oxidation and then measured using ultraviolet spectroscopy. The extract liquor was digested with alkaline auto-oxidation using $0.15 \mathrm{~mol} \mathrm{~L}^{-1} \mathrm{NaOH}$ and $30 \mathrm{~g} \mathrm{~L}^{-1} \mathrm{~K}_{2} \mathrm{~S}_{2} \mathrm{O}_{8}$ with a 1:1 v/v mixture of oxidant and soil at 120-124 for 30 min [54]. The concentration of $\mathrm{N}$ was determined colorimetrically using a spectrophotometer (UV2300, Hitachi, Tokyo, Japan) at 220 and $275 \mathrm{~nm}$. A $k_{N}$ value of 0.54 was chosen to calculate the total soil microbial biomass $\mathrm{N}$ [47]. The soil microbial $\mathrm{P}$ level was determined calorimetrically with a spectrophotometer. $2.5 \mathrm{~g}$ of fumigated and unfumigated soil was placed into a $150-\mathrm{ml}$ flask containing $50 \mathrm{ml}$ of $0.5 \mathrm{~mol} \mathrm{~L}^{-1}$ $\mathrm{NaHCO}_{3}$ solution and $2 \mathrm{~g}$ of P-free active charcoal. $5 \mathrm{ml}$ of Mo-Sb spectrochrometry solution was added for color development. After 30 min, the color was determined with a spectrophotometer (UV2300, Hitachi, Tokyo, Japan) at $700 \mathrm{~nm}$. The microbial $P$ was calculated using a $k_{p}$ factor of $0.40[2,14]$.

\subsection{Statistical analysis}

Variety statistical analyses were conducted using SPSS 18.0 to identify the effects of the successional grassland restoration years on soil microbiological parameters. One-way analysis of variance (ANOVA) with restoration years and soil aggregate sizes as the main factors were employed to test the significance of the mean differences. The level set for a significant difference was $p<0.05$. A univariate procedure was used to examine the normality of the distribution of the observed data before conducting the ANOVA analysis. When the ANOVA test indicated a significant effect at $p<0.05$, the means of each soil variable for each classification factor were assessed using the multiple-mean comparison that was assessed using the Benjamini False Discovery Ratio method. In order to explore the relationship between soil microbial biomass and soil physiochemical properties, we used canonical correlation analysis which is more effective analysis than the simple correlation analysis (Table 1).

\section{Results}

\subsection{Basic soil characteristics}

General soil characteristics for the various restoration years are shown in Table 2. As grassland recovery years increased, maximum field capacity (MFC), porosity (Por.), soil organic carbon (SOC), total nitrogen (TN), rapid available phosphorus (Ap-P), invertase (Inv), Alkal-phosphatase (Alk.-P), soil microbial biomass carbon $\left(C_{\text {mic }}\right)$ and phosphorus $\left(P_{\text {mic }}\right)$ also increased. However, restoration years also resulted in a decrease in bulk density (BD). The highest concentrations of soil microbial biomass nitrogen $\left(\mathrm{N}_{\text {mic }}\right.$ ), urease (Ure) and rapid available potassium (Ap-K) were found in 10 year grassland. The distribution of aggregate size class percentage varied among the grassland restoration sites (Fig. 1). The percentage of $<0.25$ and $>5 \mathrm{~mm}$ aggregate sizes in 30 year natural
Table 1 Sampling site characteristics

\begin{tabular}{|c|c|c|c|c|}
\hline $\begin{array}{l}\text { Successional } \\
\text { years }\end{array}$ & Dominant species & Accompanying species & Elevation (m) & $\begin{array}{l}\text { Slope } \\
\text { gradient } \\
\left({ }^{\circ}\right)\end{array}$ \\
\hline 30 & $\begin{array}{l}\text { Thymus mongolicus } \\
\text { Stipa bungana }\end{array}$ & $\begin{array}{l}\text { Stipa grandiss } \\
\text { Artemisia sacrorum. } \\
\text { Artamisia scoparia }\end{array}$ & 1930 & 12 \\
\hline 10 & $\begin{array}{l}\text { Leymus secalinus } \\
\text { Thymus mongolicus }\end{array}$ & $\begin{array}{l}\text { Artemisia scoparia } \\
\text { Potentilla bifurca } \\
\text { Stipa bungana }\end{array}$ & 1908 & 11 \\
\hline 1 & $\begin{array}{l}\text { Artemisia scoparia } \\
\text { Potentilla bifurca }\end{array}$ & $\begin{array}{l}\text { Thymus mongolicus } \\
\text { Heteropappus altaicus } \\
\text { Thymus mongolicus } \\
\text { Stipa bungana }\end{array}$ & 1940 & 10 \\
\hline
\end{tabular}


Table 2 Basic soil characteristics

\begin{tabular}{lrrr}
\hline Soil characteristics & \multicolumn{3}{c}{ Successional years } \\
\cline { 2 - 4 } & 30 years & 10 years & 1 year \\
\hline BD & 0.91 & 1.13 & 1.28 \\
MFC & 37.08 & 31.83 & 27.34 \\
Por. & 54.85 & 54.80 & 50.36 \\
SOC & 27.85 & 18.15 & 9.50 \\
TN & 3.10 & 1.88 & 1.17 \\
Ap-P & 3.56 & 3.37 & 2.71 \\
Ap-K & 166.24 & 241.69 & 153.04 \\
$\mathrm{NH}_{4}{ }^{+}-\mathrm{N}$ & 14.08 & 4.21 & 4.53 \\
$\mathrm{NO}_{3}{ }^{-}-\mathrm{N}$ & 16.62 & 6.40 & 15.06 \\
C:N $^{\mathrm{N}}$ & 8.87 & 8.26 & 8.26 \\
Inv. & 20.40 & 14.77 & 7.83 \\
Alk.-P & 12.43 & 9.99 & 5.95 \\
Ure. & 2.62 & 4.13 & 3.64 \\
$\mathrm{C}_{\text {mic }}$ & 1065.49 & 683.72 & 358.96 \\
$\mathrm{~N}_{\text {mic }}$ & 25.78 & 41.41 & 17.23 \\
$\mathrm{P}_{\text {mic }}$ & 19.99 & 15.74 & 2.56 \\
\hline
\end{tabular}

BD: soil bulk density $\left(\mathrm{g} \mathrm{cm}^{3}\right)$; MFC: maximum field capacity (\%); Por.: porosity (\%); SOC: soil organic carbon $\left(\mathrm{g} \mathrm{kg}^{-1}\right)$; $\mathrm{TN}$ : total nitrogen $\left(\mathrm{g} \mathrm{kg}^{-1}\right)$; Ap-P: rapid available phosphorus $\left(\mathrm{mg} \mathrm{kg}^{-1}\right)$; Ap-K: rapid available potassium $\left(\mathrm{mg} \mathrm{kg}^{-1}\right) ; \mathrm{NH}_{4}{ }^{+}-\mathrm{N}$ : soil ammonium nitrogen $\left(\mathrm{mg} \mathrm{kg}^{-1}\right) ; \mathrm{NO}_{3}-\mathrm{N}$ : soil nitrate nitrogen $\left(\mathrm{mg} \mathrm{kg}^{-1}\right)$; Inv.: invertase $\left(\mathrm{mg} \mathrm{g}^{-1}\right)$; Alk.-P: Alkal-phosphatase $\left(\mathrm{mg} \mathrm{g}^{-1}\right)$; Ure.: urease $\left(\mathrm{mg} \mathrm{g}^{-1}\right)$; $C_{\text {mic }}$ : soil microbial biomass $\left(\mathrm{mg} \mathrm{kg}^{-1}\right) ; \mathrm{N}_{\text {mic }}$ : soil microbial nitrogen $\left(\mathrm{mg} \mathrm{kg}^{-1}\right) ; \mathrm{P}_{\text {mic }}$ : soil microbial phosphorus $\left(\mathrm{mg} \mathrm{kg}^{-1}\right)$

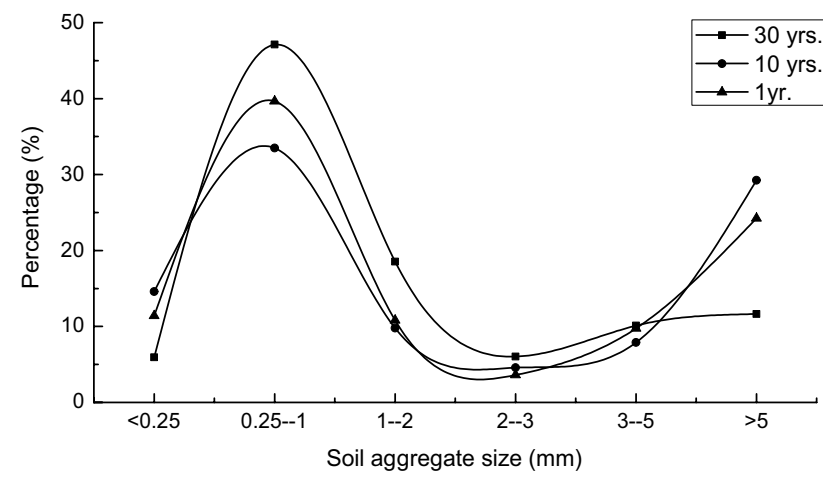

Fig. 1 Effect of restoration years on the distributions of aggregate sizes' percentage

grassland was lower than in 10 year. Lastly, soil aggregate composition in 30 year grassland was mainly concentrated between 0.25 and $5 \mathrm{~mm}$.

\subsection{Distribution of SOC and TN in various aggregate sizes}

The concentration of SOC and TN associated with soil grain size increased with the number of years of grassland succession (Fig. 2a, c). For 10- and 30-year natural grassland, the percentage of SOC in 1-2, 2-3 and 3-5 mm was higher than for other aggregate sizes. In 1 year abandoned grassland, the macro-aggregate size $(>5 \mathrm{~mm}$ ) showed the greatest SOC with rapid enhancement between 3-5 and $5 \mathrm{~mm}$ (Fig. 2b). The trend in distribution of TN among the various aggregate classes in 10- and 30-year natural grassland was similar (i.e., stable between 15.79 and 17.64). However, significant changes occurred in 1 year-abandoned grassland (Fig. 2d). The percentage of TN (11.26) was lowest for micro-aggregates $(<0.25 \mathrm{~mm})$, highest in 0.25-1 mm (19.22), and remained at a lower yet steady level for 10- and 30-year (17.02-18.51).

\subsection{The distribution of soil microbial parameters at different aggregate sizes}

\subsubsection{Soil microbial biomass}

The concentrations of $C_{\text {mic }}$ and $P_{\text {mic }}$ at different grain sizes increases with length of grassland succession (Fig. 3a, e). The situation with $\mathrm{N}_{\text {mic }}$ is different where it had the highest value in a 10 year natural grassland (Fig. 3c).

Under a 30 year natural grassland, the percentage of $C_{\text {mic }}$ (18.59) was greatest for a micro-aggregate size of $<0.25 \mathrm{~mm}$, as aggregate size increased, percentages dropped to a stable range between 15.68 and 16.56 . At 10 years, a grain size of $1-2 \mathrm{~mm}$ showed the greatest percentage of $C_{\text {mic }}$ (18.4), which was a rapid increase from $<0.25$. The percentage of $C_{\text {mic }}$ for other particle sizes remained at a stable level between 16.72 and 17.61 (Fig. 3b). The curve of $C_{\text {mic }}$ versus aggregate size for a recently abandoned grassland fluctuated greatly. There was a significant decrease in percentage of $C_{\text {mic }}$ in 2-3 $\mathrm{mm}$ versus $1-2,3-5$ and $>5 \mathrm{~mm}$. In a 30-year natural grassland, the percentage of $\mathrm{N}_{\text {mic }}$ remained stable between 14.99 and 18.48 for the various aggregate sizes. As soil aggregate size increased, the distribution of $\mathrm{N}_{\text {mic }}$ in 1- and 10-year grassland showed a rising tendency and declining trend, respectively (Fig. 3d). The percentage of $P_{\text {mic }}$ in different aggregate sizes for 10- and 30-year natural grassland remained stable. Whereas, for the highest percentage occurring in aggregate sizes of $2-3 \mathrm{~mm}$, the 1-year curve showed a "normal distribution" which was significantly enhanced from $0.25-1 \mathrm{~mm}$ and rapidly declined at 2-3 mm (Fig. 3f).

\subsection{Soil microbial basal respiration and metabolic quotient}

Soil microbial basal respiration (SBR) was enhanced as the successional years increased (Fig. 4a). For a grassland abandoned for 1 year, the percentage of SBR in $<0.25$ 


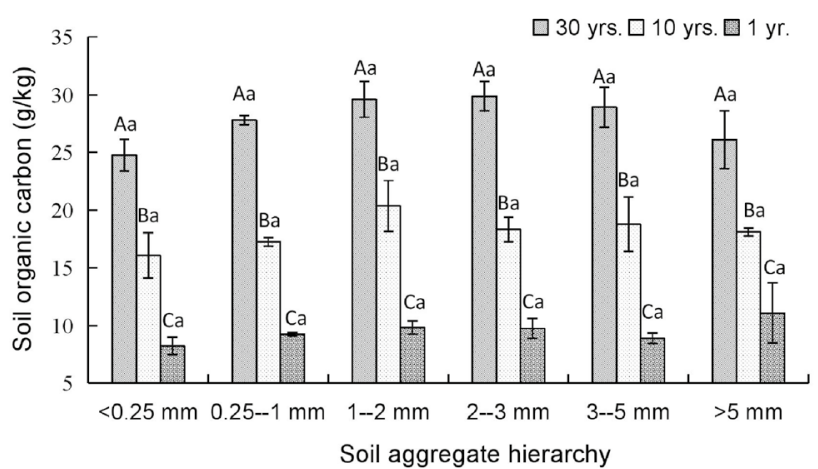

(a)

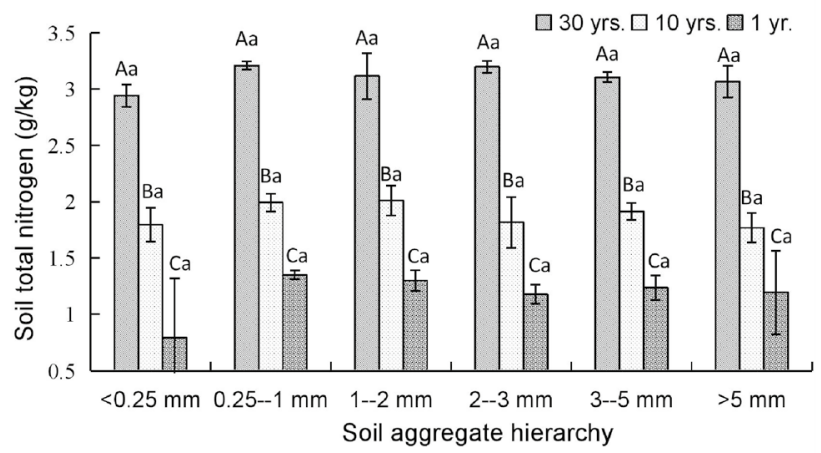

(c)

Fig. 2 Effect of restoration years on SOC and TN for different aggregate sizes. a The distribution of SOC in different vegetation restoration years; $\mathbf{b}$ The percent distribution of SOC in soil aggregate size; c The distribution of TN in different vegetation restoration years; d The percent distribution of TN in soil aggregate size. Different

and $0.25-1 \mathrm{~mm}$ was lower than in other aggregate sizes. SBR increased with aggregate size, the highest occurring between 3 and $5 \mathrm{~mm}$. The curve of SBR for a 30-year natural grassland for different aggregate size classes fluctuated, it was the highest in 3-5 $\mathrm{mm}$ and lowest in $2-3 \mathrm{~mm}$. However, the percentage at 10 years increased with soil aggregate size (Fig. 4b). Soil microbial metabolic quotient $\left(q \mathrm{CO}_{2}\right)$ among the aggregate size classes had the opposite reaction as restoration years increased (Fig. 4c). In a grassland abandoned for 10 years, the percentage of $q \mathrm{CO}_{2}$, in aggregate size classes of $0.25-1,1-2$ and $2-3 \mathrm{~mm}$, was lower than in the micro-aggregate $(<0.25 \mathrm{~mm})$ and macroaggregate (3-5 $\mathrm{mm}$ and $>5 \mathrm{~mm}$ ) classes (Fig. $4 \mathrm{~d}$ ).

\subsection{The ratios of $\mathrm{C} / \mathrm{N}, \mathrm{C}_{\text {mic }} / \mathrm{N}_{\text {mic }}$ and $\mathrm{C}_{\text {mic }} / \mathrm{P}_{\text {mic }}$}

The ratios of $\mathrm{C} / \mathrm{N}, \mathrm{C}_{\text {mic }} / \mathrm{N}_{\text {mic }}$ and $\mathrm{C}_{\text {mic }} / \mathrm{P}_{\text {mic }}$ for the different aggregate sizes in the three successional periods were

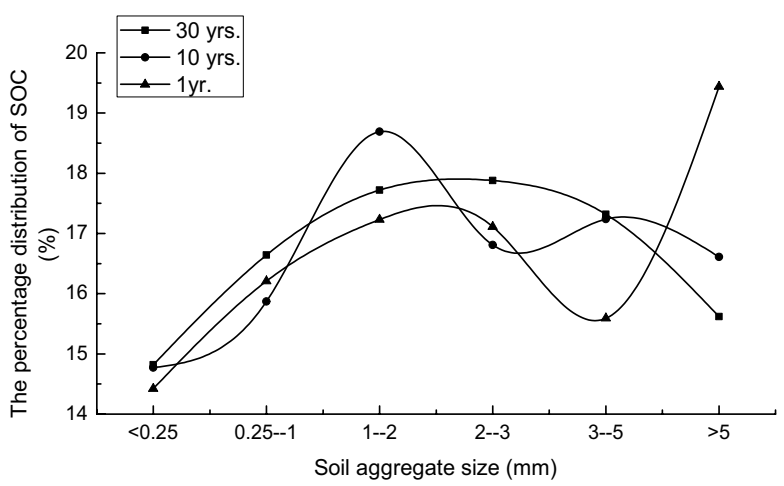

(b)

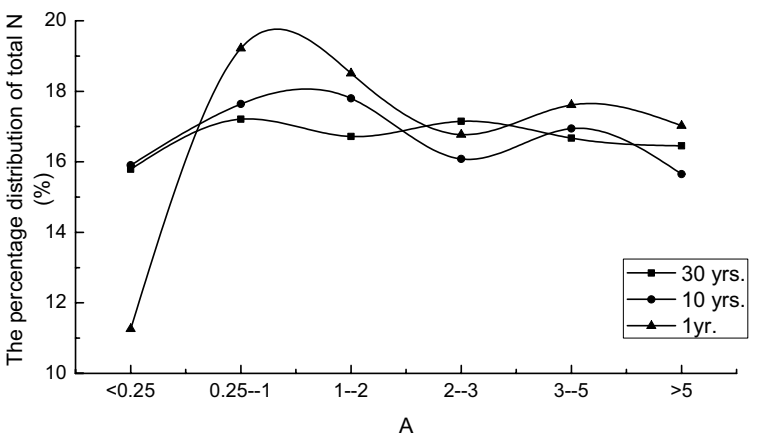

(d)

capital letters within columns indicate statistically significant differences among the different restoration years, different lowercase letters within columns indicate statistically significant differences among the different soil aggregate size $(p<0.05)$

shown in Table 3. The greatest ratios of $\mathrm{C} / \mathrm{N}, \mathrm{C}_{\text {mic }} / \mathrm{N}_{\text {mic }}$ and $C_{\text {mic }} / P_{\text {mic }}$ were exhibited in the 10 year, 30 year and 1 year grasslands, respectively.

For the 10- and 30-year natural successional grasslands, the ratios of $\mathrm{C} / \mathrm{N}$ in aggregate size of $1-2,2-3$ and $3-5 \mathrm{~mm}$ were higher than the others. The ratios of $\mathrm{C}_{\text {mic }} / \mathrm{P}_{\text {mic }}$ in grassland under succession for 30 years was greater in $<0.25,0.25-1$ and $>5 \mathrm{~mm}$ and were between 43.11 and 46.25 in grassland under succession for 10 years, expect $<0.25 \mathrm{~mm}$ which had the lowest value. For a grassland under restoration for one year, the ratios show a $V$ shaped distribution among the soil aggregate sizes, with the lowest ratio occurring in $2-3 \mathrm{~mm}$. The ratio of $\mathrm{C}_{\text {mic }} / \mathrm{N}_{\text {mic }}$ in grassland that was in a natural state for 30 years was maintained at a stable level (37.03-42.02), but, at 10 years, the ratio increased as soil aggregate size increased. For a grassland abandoned for 1 year, the ratio was greatest for $<0.25 \mathrm{~mm}$ and lowest for $>5 \mathrm{~mm}$, the other ratios were between 9.32 and 25.96 . 


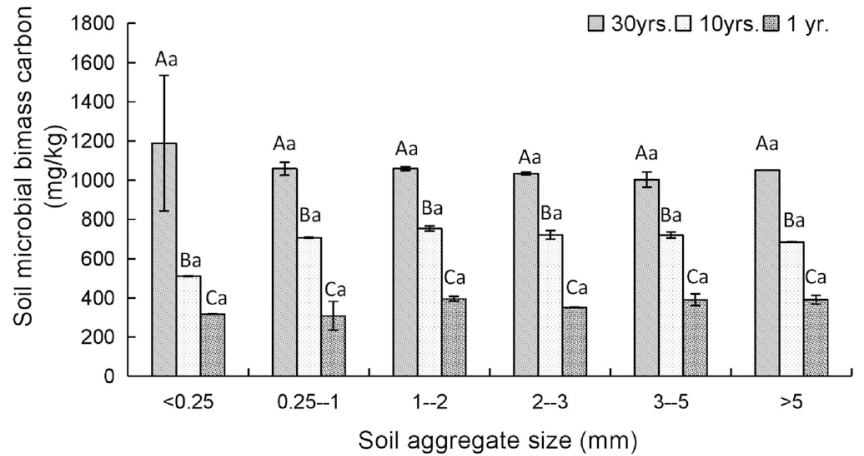

(a)

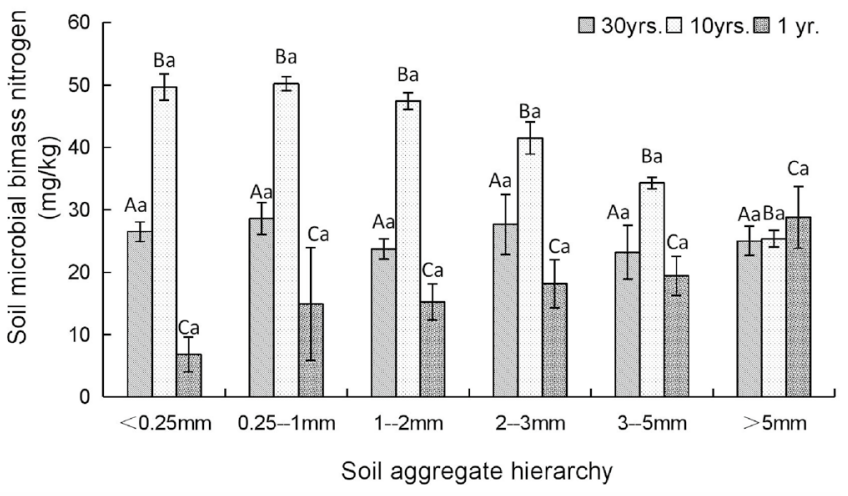

(c)

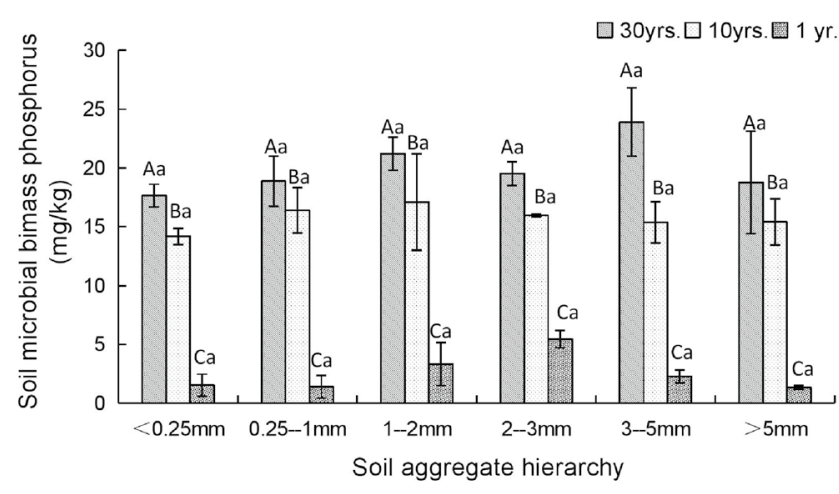

(e)

Fig. 3 Effect of restoration years on $\mathrm{C}_{\text {mic }}, \mathrm{N}_{\text {mic }}$ and $\mathrm{P}_{\text {mic }}$ in different aggregate sizes. a The distribution of $C_{\text {mic }}$ in different grassland restoration years; $\mathbf{b}$ The percentage distribution of $C_{m i c}$ in soil aggregate size; $\mathbf{c}$ The distribution of $\mathrm{N}_{\text {mic }}$ in different grassland restoration years; $\mathbf{d}$ The percentage distribution of $\mathrm{N}_{\text {mic }}$ in soil aggregate size; $\mathbf{e}$ The distribution of $\mathrm{P}_{\text {mic }}$ in different grassland restoration

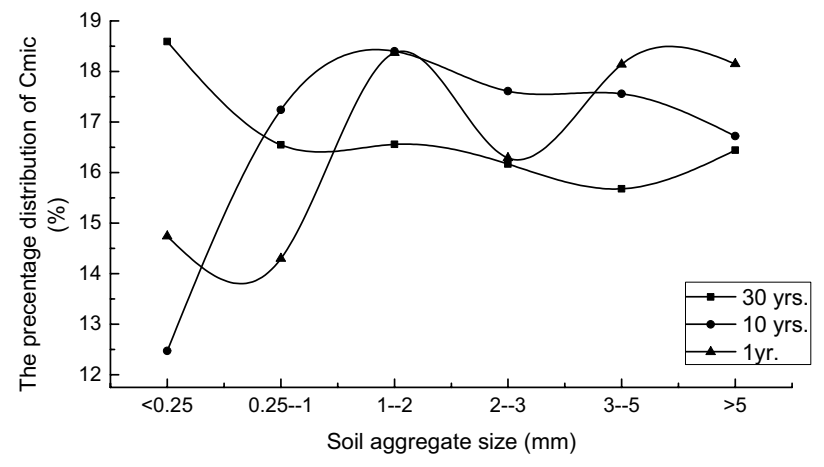

(b)

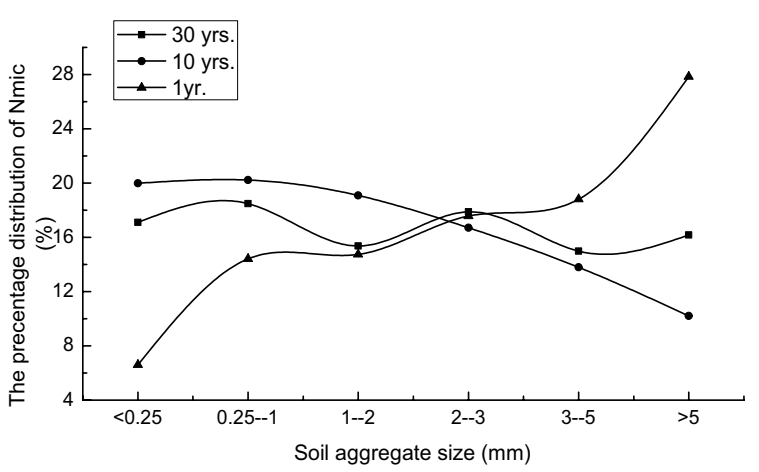

(d)

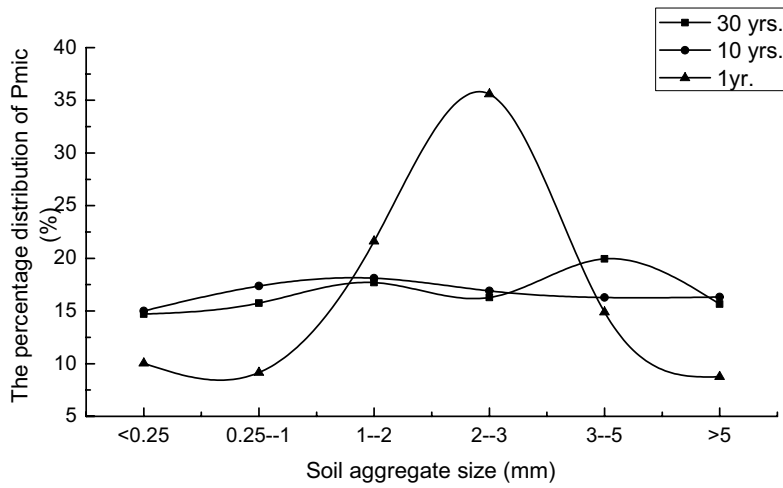

(f)

years; $\mathbf{f}$ The percentage distribution of $P_{\text {mic }}$ in soil aggregate sizes. Different capital letters within columns indicate statistically significant differences among the different restoration years, different lowercase letters within columns indicate statistically significant differences among the different soil aggregate size $(p<0.05)$ 


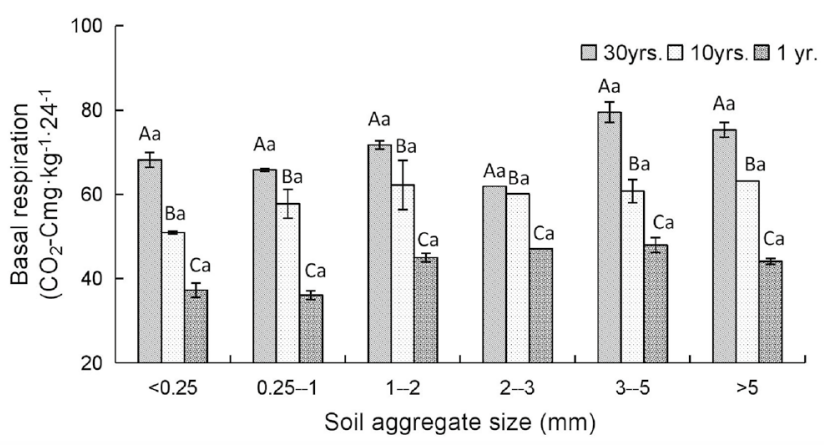

(a)

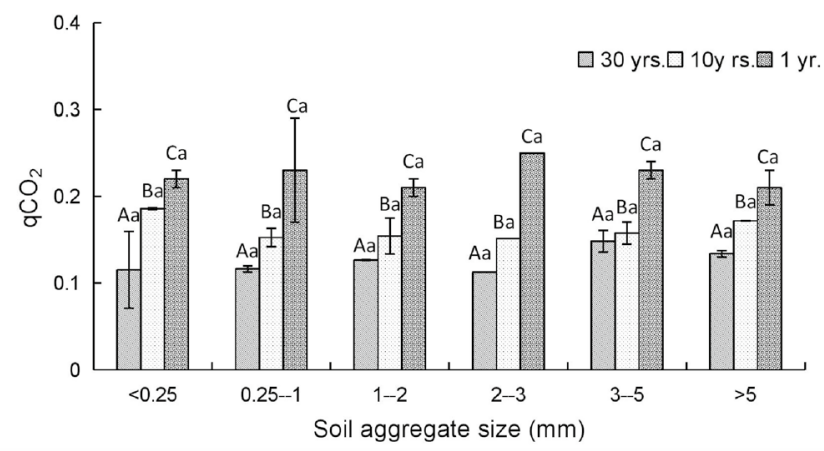

(c)

Fig. 4 Effect of restoration years on SBR and $q \mathrm{CO}_{2}$ in different aggregate sizes. a The distribution of SBR for different grassland restoration years; $\mathbf{b}$ The percent distribution of SBR in soil aggregate sizes; c The distribution of $q \mathrm{CO}_{2}$ for different grassland restoration years; $\mathbf{d}$ The percent distribution of $q \mathrm{CO}_{2}$ in soil aggregate

\subsection{The relationship of soil microbial parameters and chemical characteristics}

Significant correlations were found between soil microbial properties and chemical characteristics. As Table 4 shows, a correlation exists among the soil microbial properties that were significantly correlated with SOC, TN and Ap-P. $\mathrm{N}_{\text {mic }}$ did not relate to $\mathrm{SBR}$ and $q \mathrm{CO}_{2}$, and only correlated with $\mathrm{NO}_{3}{ }^{-}-\mathrm{N} . \mathrm{C}_{\text {mic }}$ and $\mathrm{P}_{\text {mic }}$ were significantly correlated with SBR, $q \mathrm{CO}_{2}$ and $\mathrm{C}_{\text {mic }} / \mathrm{N}_{\text {mic }}(p<0.01)$. The ratio of $\mathrm{C}_{\text {mic }} / \mathrm{P}_{\text {mic }}$ was negatively correlated with $C_{\text {mic }}(R=-0.638, p<0.01)$, $\mathrm{N}_{\text {mic }}(\mathrm{R}=-507, p<0.05), \mathrm{P}_{\text {mic }}(\mathrm{R}=-0.833, p<0.01)$ and $\mathrm{SBR}$ $(\mathrm{R}=-0.727, p<0.01)$, and positively correlated with $q \mathrm{CO}_{2}$ $(\mathrm{R}=0.635, p<0.01)$.

Table 5 shows that soil microbial metabolic quotient $\left(q \mathrm{CO}_{2}\right)$ was positively related to $C_{\text {mic }}(\mathrm{R}=0.954)$ and negatively correlated to $P_{\text {mic }}(R=-0.901)$, the correlation ratios were significant $(p<0.01)$. The correlation between $C_{\text {mic }}$ and $q \mathrm{CO}_{2}, \mathrm{P}_{\text {mic }}$ and $q \mathrm{CO}_{2}$ in different aggregate sizes is shown in Figs. 5 and 6 . The correlation coefficients for $C_{\text {mic }}$

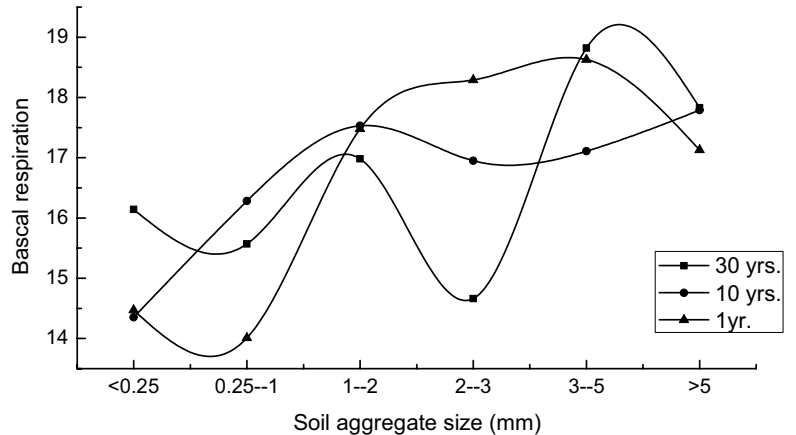

(b)

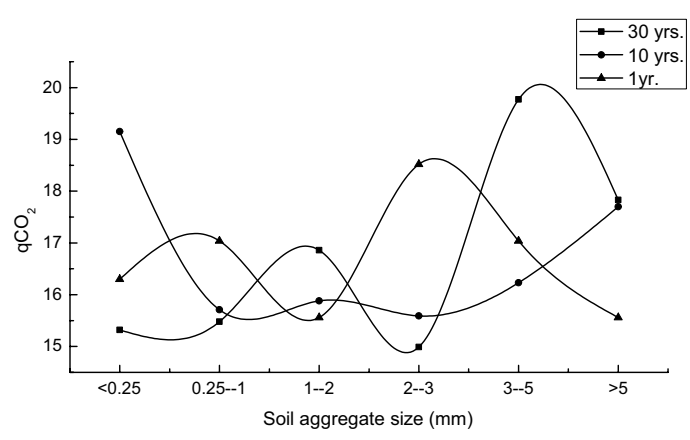

(d)

sizes. Different capital letters within columns indicate statistically significant differences among the different restoration years, different lowercase letters within columns indicate statistically significant differences among the different soil aggregate size $(p<0.05)$

and $q \mathrm{CO}_{2}, \mathrm{P}_{\text {mic }}$ and $q \mathrm{CO}_{2}$ in $<0.25,0.25-1,1-2$ and $>5 \mathrm{~mm}$ were higher $(0.9177-0.9804,0.8288-0.989)$ than in $2-3$ $(0.7427,0.7679)$ and $3-5 \mathrm{~mm}$ (Fig. $5 \mathrm{~d}, \mathrm{f})$.

\section{Discussion}

Soil microorganisms are potential indicators involved in several biological processes [56] and can be used to evaluate the success of revegetation in disturbed soil ecosystems [1]. Simultaneously, the formation and stability of soil aggregates are affected by many factors, such as plant roots, microorganisms, and soil organic matter content, and their interactions [40]. Following the longterm grassland succession, it is still unclear how vegetation restoration affects the soil aggregate distribution and soil microbial characteristics in aggregates of different size classes, as well as the potential interaction between soil microorganisms and soil aggregate size. 
Table 3 The ratios of $\mathrm{C} / \mathrm{N}, \mathrm{C}_{\text {mic }} / \mathrm{N}_{\text {mic }}$ and $\mathrm{C}_{\text {mic }} / \mathrm{P}_{\text {mic }}$ for different aggregate sizes

\begin{tabular}{llrrl}
\hline $\begin{array}{l}\text { Succes- } \\
\text { sional years }\end{array}$ & Size classes $(\mathrm{mm})$ & $\mathrm{C} / \mathrm{N}$ & $\mathrm{C}_{\text {mic }} / \mathrm{P}_{\text {mic }}$ & $\mathrm{C}_{\text {mic }} / \mathrm{N}_{\text {mic }}$ \\
\hline 30 & $<0.25$ & & & \\
\hline & $0.25-1$ & 8.42 & 67.38 & 44.92 \\
& $1-2$ & 9.51 & 46.05 & 37.03 \\
& $2-3$ & 9.35 & 52.98 & 44.57 \\
& $3-5$ & 9.32 & 41.93 & 43.37 \\
& $>5$ & 8.52 & 56.01 & 42.02 \\
Mean & & 8.97 & 54.04 & 41.53 \\
& $<0.25$ & 8.95 & 36.09 & 10.30 \\
& $0.25-1$ & 8.67 & 43.11 & 14.08 \\
& $1-2$ & 10.12 & 44.13 & 15.91 \\
& $2-3$ & 10.08 & 45.25 & 17.41 \\
& $3-5$ & 9.81 & 46.87 & 21.02 \\
& $>5$ & 10.23 & 44.53 & 27.04 \\
Mean & & 9.64 & 43.33 & 17.62 \\
& $<0.25$ & 10.40 & 206.01 & 46.49 \\
& $0.25-1$ & 6.85 & 218.87 & 20.67 \\
& $1-2$ & 7.56 & 119.22 & 25.96 \\
& $2-3$ & 8.29 & 64.21 & 19.32 \\
& $3-5$ & 7.19 & 170.75 & 20.10 \\
& $>5$ & 9.28 & 290.95 & 13.58 \\
\hline \multirow{4}{*}{10} & & &
\end{tabular}

Soil microbial biomass, soil basal respiration and metabolic quotient are commonly used as "bio-markers" to assess soil quality [25], and have been previously considered to be sensitive parameters of evaluating natural and degraded systems $[6,55]$. In this study, the results showed that soil microbial biomass $C$ and $P$ were enhanced in the vegetation restoration, and this enhancement was positively correlated with soil micro-aggregate size. A widely accepted theory of soil aggregation formation is the phase theory proposed by Tisdall and Oades [44], which stated that soil micro-aggregates are generated from soil mineral particles through binding of multivalentions and soil organic matter, and then the micro-aggregateds and held together by plant roots and fungal hyphae to gradually form larger aggregates. Although the variation in different soil aggregate proportions was not correlated with the amount of soil microbial indicators, the $C_{\text {mic }}$ content in micro-aggregate size class $(<0.25,0.25-1,1-2 \mathrm{~mm})$ was linearly correlated with restoration years increased.

Such interactions between vegetation and soil microbes are reflected by the fact that changes in microbial composition, activity, and biomass largely resulted from the higher litter quality of vegetation associated with great diversity [58]. In the present study, SOC, TN and Ap-P (chemical characteristics); Inv., Alk-P (soil enzyme activities); $C_{\text {mic }}$ and $P_{\text {mic }}$ (soil microbial biomass) increased with an increase in restoration years. This finding is similar with a previous study conducted by Yan et al. [55] who reported soil microbial community composition significantly changed with vegetation succession. Gupta and Germida [13] proposed the microbial biomass plays an important role in the formation of macro-aggregates and is the primary resource of labile organic carbon and nutrients. Relative to the macro-aggregates $(>0.25 \mathrm{~mm}$ ) contained lower organic carbon, microbial biomass, fungal
Table 4 Correlation coefficients between basic characteristics and soil microbial parameters

\begin{tabular}{|c|c|c|c|c|c|c|c|}
\hline & SOC & Total N & $\mathrm{NO}_{3}-\mathrm{N}$ & $\mathrm{NH}_{4}-\mathrm{N}$ & Ap-K & $A p-P$ & $\mathrm{C} / \mathrm{N}$ \\
\hline$C_{\text {mic }}$ & $0.965^{* *}$ & $0.964^{* *}$ & 0.155 & -0.269 & 0.087 & $0.574^{*}$ & 0.259 \\
\hline $\mathrm{N}_{\text {mic }}$ & 0.268 & 0.206 & $-0.704^{* *}$ & -0.106 & 0.046 & 0.035 & 0.312 \\
\hline$P_{\text {mic }}$ & $0.933^{* *}$ & $0.883^{* *}$ & -0.106 & -0.208 & 0.406 & $0.677^{* *}$ & 0.422 \\
\hline SBR & $0.910^{* *}$ & $0.882^{* *}$ & 0.046 & -0.098 & 0.207 & $0.672^{* *}$ & 0.326 \\
\hline$q \mathrm{CO}_{2}$ & $-0.932^{* *}$ & $-0.906^{* *}$ & 0.035 & 0.395 & -0.267 & $-0.473^{* *}$ & -0.463 \\
\hline
\end{tabular}

*Significant at the 0.05 level; **Significant at the 0.01 level

\begin{tabular}{llllllll}
\hline & $\mathrm{C}_{\text {mic }}$ & $\mathrm{N}_{\text {mic }}$ & $\mathrm{P}_{\text {mic }}$ & $\mathrm{SBR}$ & $q \mathrm{CO}_{2}$ & $\mathrm{C}_{\text {mic }} / \mathrm{N}_{\text {mic }}$ & $\mathrm{C}_{\text {mic }} / \mathrm{P}_{\text {mic }}$ \\
\hline $\mathrm{C}_{\text {mic }}$ & 1 & & & & & & \\
$\mathrm{~N}_{\text {mic }}$ & 0.250 & 1 & & & & & \\
$\mathrm{P}_{\text {mic }}$ & $0.903^{* *}$ & $0.486^{* *}$ & 1 & & & & \\
$\mathrm{SBR}$ & $0.917^{* *}$ & 0.305 & $0.933^{* *}$ & 1 & & & \\
$q \mathrm{CO}_{2}$ & $0.954^{* *}$ & -0.414 & $-0.901^{* *}$ & $0.841^{* *}$ & 1 & & \\
$\mathrm{C}_{\text {mic }} / \mathrm{N}_{\text {mic }}$ & $0.593^{* *}$ & $0.548^{* *}$ & 0.369 & $0.472^{*}$ & -0.463 & 1 & \\
$\mathrm{C}_{\text {mic }} / \mathrm{P}_{\text {mic }}$ & $-0.638^{* *}$ & $-0.507^{*}$ & $-0.833^{* *}$ & $-0.727^{* *}$ & $0.635^{* *}$ & 0.142 & 1 \\
\hline
\end{tabular}

*Significant at the 0.05 level; **Significant at the 0.01 level
Table 5 Correlation coefficients for soil microbial biomass and respiration
SN Applied Sciences 


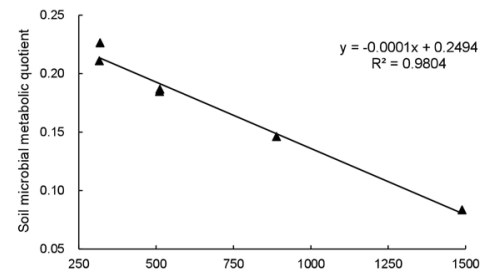

(a) $<0.25 \mathrm{~mm}$

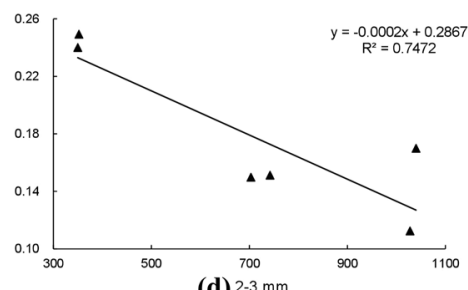

(d) $2-3 \mathrm{~mm}$

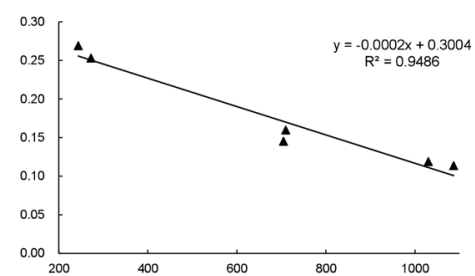

(b) $0.25-1 \mathrm{~mm}$

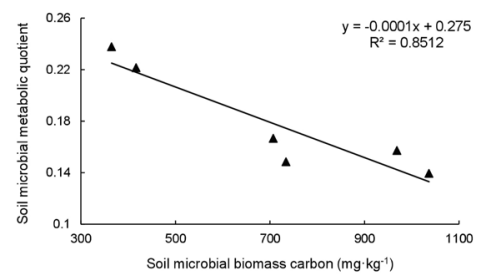

(e) $3-5 \mathrm{~mm}$

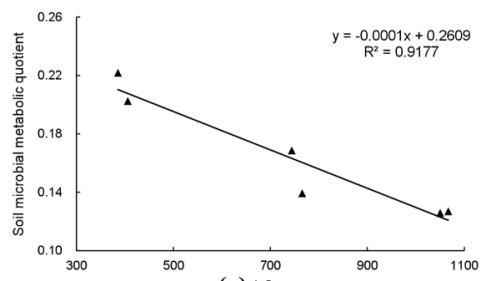

(c) ${ }^{1-2} \mathrm{~mm}$

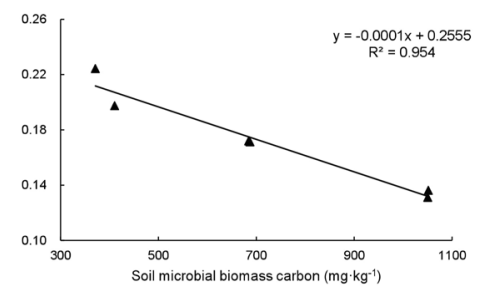

(f) $>5 \mathrm{~mm}$

Fig. 5 The relationship between $\mathrm{C}_{\text {mic }}$ and $q \mathrm{CO}_{2}$ among different aggregate sizes

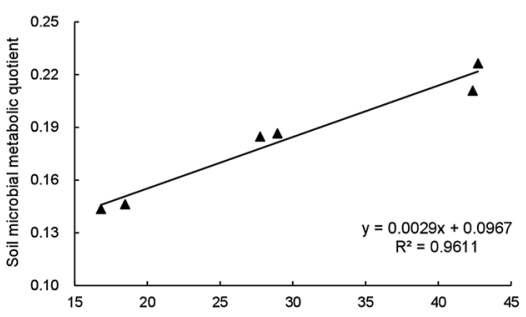

(a) $<0.25 \mathrm{~mm}$

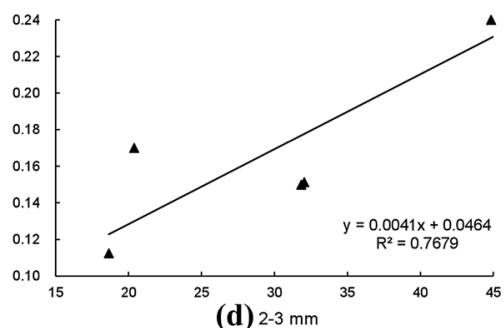

(d) $2-3 \mathrm{~mm}$

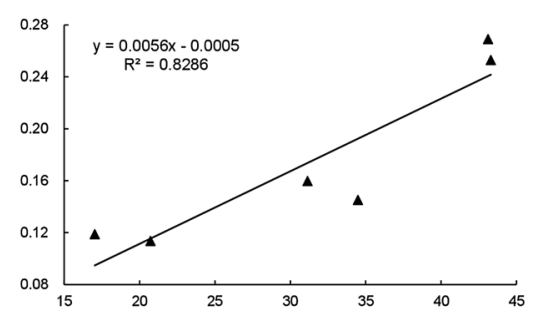

(b) $0.25-1 \mathrm{~mm}$

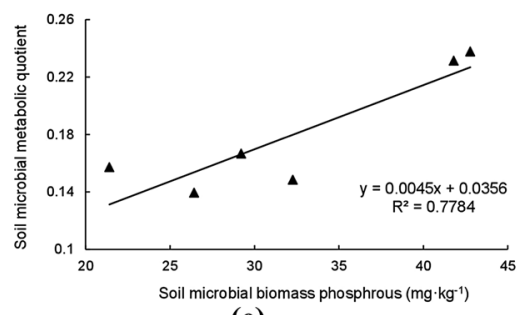

(e) $3-5 \mathrm{~mm}$

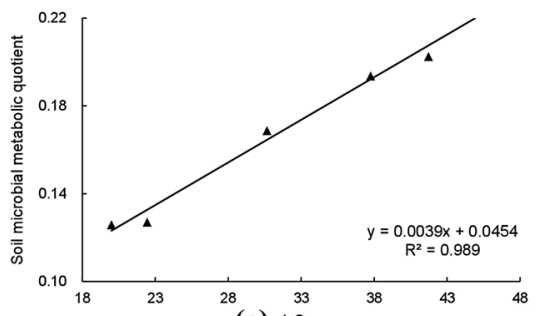

(c) $1-2 \mathrm{~mm}$

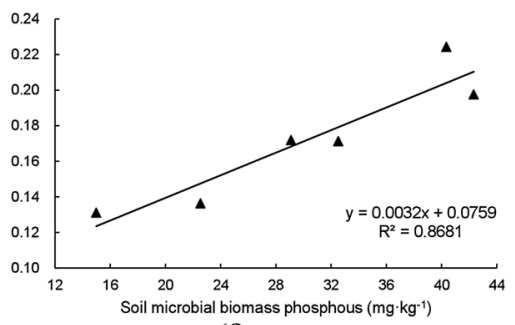

(f) $>5 \mathrm{~mm}$

Fig. 6 The relationship between $\mathrm{P}_{\text {mic }}$ and $q \mathrm{CO}_{2}$ among different aggregate sizes

biomass, and respiratory activity, with a slow turnover rate of organic carbon.

Natural grassland flourished when grazing was prohibited. The vegetative species and composition change as the vegetation restoration years increase, which impacts the soil microbial community in a direct way. An extensive root system provides the most improvement in soil structure by binding macro-aggregates to fine roots and VAM fungal hyphae and by binding micro-aggregates with adhesive bacterial metabolic products [26, 45, 52]. The natural grassland with 30 years restoration has a species-rich plant community that protects soil from physical disturbance [33], and higher soil organic matter supports an abundant carbon source for the growth of microorganisms and metabolism [41,42], which results in the highest amounts of $C_{\text {mic }}$ and $P_{\text {mic }}$. Simultaneously, the percentage of $C_{\text {mic }}$ at different aggregate sizes was stable [43].

Soil's basal respiration indicates the general activity or energy expended by its own microbial pool. The ratio of soil basal respiration to microbial biomass was the most sensitive indicator of quantitative and qualitative changes in microbial communities caused by various management systems [20]. Soil respiration relies on a suite of complex processes contributing to $\mathrm{CO}_{2}$ efflux from soil surface, mainly from plant roots and micro-organisms [22]. Many 
studies showed the changes in soil respiration and soil microbiological properties with succession $[27,28,39]$.

In this study, soil basal respiration was enhanced as natural restoration years increased with the highest concentrations found at the macro-aggregate level. The microbial carbon utilization is denoted by metabolic $\mathrm{CO}_{2}$ quotient. The findings of Insam and Haselwandtere [17] on two 50-year-old soil chronosequences on reclamation sites are similar. However, soil microbial metabolic quotient $\left(q \mathrm{CO}_{2}\right)$ declined as vegetation restoration years increased. In addition, some authors reported that systems having high organic matter inputs and organic compounds readily available in the soil tended to have greater microbial biomass content and activity since these are the preferred energy sources of microorganisms.The $q \mathrm{CO}_{2}$ considers both basal respiration and $\mathrm{C}_{\text {mic }}$ and has been mentioned as a superior indicator for microbial metabolic efficiency compared with basal respiration alone, particularly when differentiating soil biota responses to soil management approaches [16].

The percentage of $q \mathrm{CO}_{2}$ in micro-aggregate sizes was lower than in macro-aggregate sizes, the distributions of SOC and TN in different aggregate sizes was similar. Because $q \mathrm{CO}_{2}$ was negatively correlated with $\mathrm{SOC}$ and total $\mathrm{N}$, the decrease in $q \mathrm{CO}_{2}$ with time for the vegetated areas at different aggregate sizes resulted in competition for the available carbon source, which seemed to favor aggregate classes that needed the least amount of energy for maintenance and growth [17]. In the current study, relationships existed between $q \mathrm{CO}_{2}$ and SOC, TN, Ap-P, $C_{\text {mic }} P_{\text {mic }}$ and SBR. Especially for $C_{\text {mic }}$ and $P_{\text {mic }}$ the ratios in $2-3 \mathrm{~mm}$ were lowest ( 0.7472 and 0.7679 , respectively). This is not only due to decreases in microbial biomass and increases in respiration, but also to the diversion by soil microorganisms of growth energy toward maintenance [31]. A higher $q \mathrm{CO}_{2}$ and a lower microbial biomass may both occur late in ecosystem succession, and the relationship between the two reflects their dual response to underling stress [50]. The result demonstrate that $2-3 \mathrm{~mm}$ is the relative stabile aggregate size class in ecosystem succession.

\section{Conclusion}

Loess Plateau ecosystems are suffering serious environmental problems including natural grassland degradation due to soil and water erosion. This study shows that grassland has a positive effect on soil status as indicated by an increase in the concentration of soil nutrients and microbial biomass. As grassland restoration years increased, soil microbial biomass carbon, phosphorus and basal respiration increased. Soil microbial metabolic quotient $\left(q \mathrm{CO}_{2}\right)$ an alternative measure that changes when microbial biomass responses to disturbances, is significantly correlated to $C_{\text {mic }}$ and $P_{\text {mic }}$, the lowest ratios illustrated that $2-3 \mathrm{~mm}$ was the stablest aggregate size in the process of ecological restoration.

Acknowledgements This study was supported by the National Natural Sciences Foundation of China (41807060, 41977061), Fundamental Research Funds for the Central Universities (GK201903079).

\section{Compliance with ethical standards}

Conflict of interest The authors declare that they have no conflict of interest.

\section{References}

1. An SS, Huang YM, Zheng FL (2009) Evaluation of soil microbial indices along a revegetation chronosequence in grassland soils on the Loess Plateau, Northwest China. Appl Soil Ecol 41:286-292

2. An SS, Cheng Y, Huang YM, Liu D (2013) Effects of revegetation on soil microbial biomass, enzyme activities, and nutrient cycling on the Loess Plateau in China. Restor Ecol 5:600-607

3. Anderson TH, Domsch KH (1985) Determination of eco-physiological maintenance requirements of soil microorganisms in a dormant state. Biol Fertil Soils 1:81-89

4. Andraski BJ, Scanlon BR (2002) Thermocouple psychrometry. In: Dane JH, Topp GC (eds) Methods of soil analysis, part 4. Physical methods, no 5. Soil Science Society of America, Inc, pp 609-642

5. Belsky AJ (1992) Effects of grazing, competition, disturbance and fire on species composition and diversity in grassland communities. J Veg Sci 3(2):187-200

6. Bolinder MA, Angers DA, Gregorich EG, Carter MR (1999) The response of soil quality indicators to conservation management. Soil Sci 79:37-45

7. Cao S, Chen L, Xu C et al (2007) Impact of three soil types on afforestation in China's loess plateau:growth and survival of six tree species and their effects on soil properties. Landsc Urban Plan 83:208-217

8. Cao YQ, Xu L, Zhang Z et al (2019) Soil microbial metabolic quotient in inner Mongolian grasslands: patterns and influence factors. Chin Geogra Sci 29(6):1001-1010

9. Chen XL, Trond MH, Kine S et al (2020) Long-term effects of agricultural production systems on structure and function of the microbial community. Appl Soil Ecol 147:103387

10. Feng XM, Fu BJ, Lu N, Zeng Y, Wu BF (2013) How ecological restoration alters ecosystem services: an analysis of carbon sequestration in China's Loess Plateau. Sci Rep 3:1-5

11. Fu B, Chen L, Ma K, Zhou H, Wang J (2000) The relationships between land use and soil conditions in the hilly area of the loess plateau in northern Shaanxi, China. CATENA 39(1):69-78

12. Ghoshal N, Singh KP (1995) Effects of farmyard manure and inorganic fertilizer on the dynamics of soil microbial biomass in a tropical dryland agroecosystem. Boil Biol Biochem 30:1389-1414

13. Gupta VVSR, Germida JJ (1988) Distribution of microbial biomass and its activity in different soil aggregate size classes as affected by cultivation. Soil Biol Biochem 20(6):777-786

14. Hedley MJ, Stewart JWB (1982) Method to measure microbial phosphate in soils. Soil Biol Biochem 14:337-385 
15. Hernández-Hernández RM, López- Hernández D (2002) Microbial biomass, mineral nitrogen and carbon content in savanna soil aggregates under conventional and no-tillage. Soil Biol Biochem 34(11):1563-1570

16. Bolat İlyas (2019) Microbial biomass, basal respiration, and microbial indices of soil in diverse croplands in a region of northwestern Turkey (Bartın). Environ Monit Assess 191:695

17. Insam H, Haselwandter K (1989) Metabolic quotient of the soil microflora in relation to plant succession. Oecologia 79(2):174-178

18. Insam H, Parkinson D, Domsch KH (1989) The influence of macroclimate on soil microbial biomass levels. Soil Biol Biochem 21:211-221

19. Institute of Soil Science of Chinese Academy of Science (1981) Soil chemical and physical analysis. Shanghai Science and Technology Press, Beijing

20. Jenkinson DS (1976) The effects of biocidal treatment on metabolism in soil. IV. The decomposition of fumigated organsims in soil. Soil Biol Biochem 8:203-208

21. Jenkinson DS, Powlsoj DS (1976) The effects of biocidal treatment on metabolism in soil. I. Fumigation with chloroform. Soil Biol Biochem 8:167-177

22. Jia B, Zhou G, Wang $Y$, Wang F, Wang X (2006) Effects of temperature and soil water-content on soil respiration of grazed and ungrazed Leymus chinensissteppes, Inner Mongolia. J Arid Environ 67:60-76

23. Kerri LS, Louise EJ, Francisco JC, Mark RS, Kate MS (2002) Soil microbial community composition and land use history in cultivated and grassland ecosystems of coastal California. Soil Biol Biochem 34:1599-1611

24. Liu JJ, Zheng YM, Yan JX (2013) Succession of plant and soil microbial communities with restoration of abandoned land in the Loess Plateau, China. J Soils Sediments 13:760-769

25. Liu J, Zhang XY, Yang MR et al (2018) Toxicity assessment of chlorpyrifos-degrading fungal bio-composites and their environmental risks. Sci Rep 8:2152

26. Lynch JM, Bragg E (1985) Microorganisms and soil aggregate stability. Advances in soil science. Springer, New York, pp 133-171

27. Mathes K, Schriefer T (1985) Soil respiration during secondary succession: influence of temperature and moisture. Soil Biol Biochem 17(2):205-211

28. Nadia SS, Catherine EL, Quan H et al (2019) Natural and regenerated saltmarshes exhibit similar soil and belowground organic carbon stocks, root production and soil respiration. Ecosystems 22:1803-1822

29. Oades JM (1988) The retention of organic matter in soils. Biogeochemistry 5(1):35-70

30. Odum EP (1969) The strategy of ecosystem development. Sustainability $164: 58$

31. Paul EA (2014) Soil microbiology, ecology and biochemistry, 4th edn. Academic Press, San Diego

32. Paulina BR, Sebastián FA, Beatriz D et al (2020) Soil microbial community response to labile organic carbon fractions in relation to soil type and land use along a climate gradient. Soil Biol Biochem 141:107692

33. Pérès $G$, Cluzeau $D$, Menasseri $S$, Soussana JF, Bessler $H$, Engels M Habekost, Gleixner G, Weigelt A, Weisser WW, Scheu S, Eisenhauer N (2013) Mechanisms linking plant community properties to soil aggregate stability in an experimental grassland plant diversity gradient. Plant Soil 373(1-2):285-299

34. Peter MV, Duncan NLM, Sasha CR et al (2013) Biological nitrogen fixation: rates, patterns and ecological controls in terrestrial ecosystems. Philos Trans R Soc B 368(1621):20130119
35. Powlson DS, Brookes PC, Christensen BT (1987) Measurement of soil microbial biomass provided an early indication of changes in total soil organic matter due to straw incorporation. Soil Biol Biochem 19:159-164

36. Racheal NU, Elizabeth MB, Kirsten SH (2019) Spatio-temporal microbial community dynamics within soil aggregates. Soil Biol Biochem 132:58-68

37. Rajasekaran M, Ika D, Katharina K et al (2019) Spatial distribution of microbial biomass and residues across soil aggregate fractions at different elevations in the Central Austrian Alps. Geoderna 339:1-8

38. Reynolds HL, Packer A, Bever JD et al (2003) Grassroots ecology: plant-microbe-soil interactions as drivers of plant community structure and dynamics. Ecology 84:2284-2291

39. Shi P, Qin YL, Liu Q et al (2020) Soil respiration and response of carbon source changes to vegetation restoration in the Loess Plateau, China. Sci Total Environ 707:135507

40. Six J, Frey SD, Thiet RK et al (2006) Bacterial and fungal contributions to carbon sequestration in agroecosystems. Soil Sci Am J 70:555-569

41. Six JAET, Elliott ET, Paustian K (2000) Soil macroaggregate turnover and microaggregate formation: a mechanism for $\mathrm{C}$ sequestration under notillage agriculture. Soil Biol Biochem 32(14):2099-2103

42. Six J, Elliott ET, Paustian K (1999) Aggregate and soil organic matter dynamics under conventional and no-tillage systems. Soil Sci Soc Am J 63(5):1350-1358

43. Six J, Elliott ET, Paustian K (2000) Soil structure and soil organic matter II. A normalized stability index and the effect of mineralogy. Soil Sci Soc Am J 64(3):1042-1049

44. Tisdall J, Oades JM (1982) Organic matter and water-stable aggregates in soils. J Soil Sci 33:141-163

45. Tisdall JM, Smith SE, Rengasamy P (1997) Aggregation of soil by fungal hyhae. Aust J Soil Res 35:55-60

46. Tong LH, Zhu L, Lv YZ et al (2020) Response of organic carbon fractions and microbial community composition of soil aggregates to long-term fertilizations in an intensive greenhouse system. J Soils Sediments 20:641-652

47. Vance ED, Brookes PC, Jenkinson DS (1987) An extraction method form easuring soil microbial biomass $C$. Soil Biol Biochem 19(6):703-707

48. Wang GH (2002) Plant traits and soil chemical variables during a secondary succession on the Loess P1atean. Acta Bot Sin 44(8):990-998

49. Wardle DA (1992) A comparative assessement of factors which influence microbial biomass carbon and nitrogen levels in soil. Biol Rev 67:321-358

50. Wardle DA, Ghani A (1995) A critique of the microbial metabolic quotient $\left(q \mathrm{CO}_{2}\right)$ as a bioindicator of disturbance and ecosystem development. Soil Biol Biochem 27(12):1601-1610

51. Wu JS, Joergensen RG, Pommerening B, Chaussod R, Brookes PC (1990) Measurement of soil organic biomass-C by fumigation extraction an automated procedure. Soil Biol Biochem 22:1167-1169

52. Xiao L, Yao KH, Li P et al (2020) Increased soil aggregate stability is strongly correlated with root and soil properties along a gradient of secondary succession on the Loess Plateau. Ecol Eng 143:105671

53. Xiao SS, Ye YY, Xiao D et al (2019) Effects of tillage on soil $\mathrm{N}$ availability, aggregate size, and microbial biomass in a subtropical karst region. Soil Tillage Res 192:187-195

54. Xue ZJ, Man C, Wang WZ, An SS (2014) Plant functional traits and soil microbial biomass in different vegetation zones on the Loess Plateau. J Plant Int 2015(1):889-900 
55. Yan YJ, Dai QH, Hu G et al (2020) Effects of vegetation type on the microbial characteristics of the fissure soil -plant systems in karst rocky desertification regions of SW China. Sci Total Environ 712:136543

56. Yang W, Guo Y, Wang $X$ et al (2017) Temporal variations of soil microbial community under compost addition in black soil of Northeast China. Appl Soil Ecol 121:214-222

57. Zhang ZY, Liang SW, Wang JK et al (2018) Tillage and crop succession effects on soil microbial metabolic activity and carbon utilization in a clay loam soil. Eur J Soil Biol 88:97-104
58. Zhao Chang, Long J, Liao Hongkai et al (2019) Dynamics of soil microbial communities following vegetation succession in a karst mountain ecosystem, Southwest China. Sci Rep 9:2160

Publisher's Note Springer Nature remains neutral with regard to jurisdictional claims in published maps and institutional affiliations. 